\title{
Determining Yellow-flesh Intensity in Potatoes
}

\author{
Kathleen G. Haynes ${ }^{1}$, William E. Potts ${ }^{2}$, Jesse L. Chittams ${ }^{2}$, and Diane L. Fleck ${ }^{3}$ \\ U.S. Department of Agriculture, Agricultural Research Service, Beltsville, MD 20705
}

Additional index words. Solanum tuberosum, carotenoids, subsampling

\begin{abstract}
For the yellow-flesh fresh market, potato (Solanum tuberosum L.) varieties with intense yellow flesh are desired. Twenty-five yellow-flesh clones, including 24 U.S. Dept. of Agriculture (USDA) selections and the check variety 'Yukon Gold', were evaluated for tuber yellow-flesh color, as measured by a reflectance colorimeter, and for individual tuber weight in replicated field trials in Presque Isle, Maine, in 1991 and 1992. There were significant differences among clones for yellow-flesh intensity. Yellow-flesh intensity in two USDA selections was significantly less than in 'Yukon Gold'. In four USDA selections, yellow-flesh intensity was significantly greater than in 'Yukon Gold'. In general, there was an inverse relationship between tuber weight and yellow-flesh intensity. Subsamples of tubers whose weight fell between the 10 to 90,25 to 75,35 to 65 , and 40 to 60 percentile were compared to the full sample. There was good agreement between the 10 to 90 and 25 to 75 percentile subsample and the full sample regarding the average yellow-flesh intensity and in the consistency of pairwise comparisons between individual selections and 'Yukon Gold'. For determining yellow-flesh intensity, the 25 to 75 percentile subsample was as informative as the full sample.
\end{abstract}

There has been considerable interest in yellow-flesh potatoes for the fresh market in the United States following the introduction of 'Yukon Gold' by Agriculture Canada (Johnston and Rowberry, 1981). Most European potato varieties are yellow-flesh (Siebenick, 1959), but until recently the American market has favored whiteflesh varieties. However, in 1991, 1032.4 ha of 'Yukon Gold' was planted for certified seed in the United States and Canada (National Potato Council, 1993).

Breeding efforts are underway in several potato improvement programs to develop yellow-flesh varieties. The yellow-flesh trait is thought to be controlled by a single gene, with yellow dominant to white (Fruwirth, 1912), although there may also be modifying genes (Schick, 1956). Bonierbale et al. (1988) have mapped the yellow-flesh locus to chromosome 3. Yellow flesh in potatoes is due primarily to the xanthophylls lutein and violaxanthin (Brown et al., 1993; Iwanzik, 1983; Sinden et al., 1991).

Research on the intensity of the yellow-flesh trait within a given potato variety, differences between varieties, and the variability of yellow-flesh intensity has not been reported. To select superior breeding clones for further evaluation as potential new varieties in the yellow-flesh breeding effort, criteria need to be developed for effective selection. Intense yellow flesh would be a prerequisite for a fresh-market, yellow-flesh potato. In addition, yield and uniformity of tuber size are also important.

Evaluating every tuber for yellow-flesh intensity in even a small experiment can be time consuming and costly. Several subsampling techniques are available to reduce the amount of sampling but still maintain a certain amount of precision.

The purposes of this study were to 1) evaluate the yellow- flesh intensity of 'Yukon Gold' and 24 selections (clones) from the U.S. Dept. of Agriculture (USDA, Beltsville, Md.) potato breeding program, 2) evaluate the yield and tuber size uniformity of these 24 yellow-flesh selections in relation to the standard check variety

Received for publication 24 Jan. 1994. Accepted for publication 22 Mar. 1994. Mention of a trademark, warranty, proprietary product, or vendor does not constitute a guarantee by the U.S. Dept. of Agriculture and does not imply its approval to the exclusion of other products or vendors that may also be suitable. The cost of publishing this paper was defrayed in part by the payment of page charges. Under postal regulations, this paper therefore must be hereby marked advertisement solely to indicate this fact.

${ }^{1}$ Research geneticist. To whom reprint requests should be addressed.

${ }^{2}$ Statistician.

${ }^{3}$ Biological technician.
'Yukon Gold', and 3) develop a subsampling scheme to discriminate adequately among clones for yellow-flesh intensity.

\section{Materials and Methods}

Twenty-four advanced yellow-flesh selections from the USDA potato breeding program and the check variety 'Yukon Gold' (clones) were planted in Presque Isle, Maine, in 1991 and 1992. The experimental design was a randomized complete block with three replications. Plots consisted of five plants per clone, spaced $23 \mathrm{~cm}$ apart, in rows spaced $91 \mathrm{~cm}$ apart. In 1991 and 1992, the trials were planted at the Echo Lake Farm, Presque Isle, on a Caribou gravelly loam soil. In 1991, the trial was planted 15 May and harvested 5 Oct. In 1992, the trial was planted 18 May and harvested 7 Oct. Tubers were dug with a single-row digger, picked up by hand, and stored at $4 \mathrm{C}, 95 \%$ relative humidity, in heavy paper bags until evaluated for yellow-flesh intensity during January and February.

Yellow-flesh intensity was determined by a colorimeter (Colorgard System 1000; Byk-Gardner, Silver Spring, Md.) programmed to calculate a yellowness index (YI E-313) from two scales (American Society for Testing Materials, 1991). Tubers were removed from cold storage during the winter, individual tuber weights were recorded to the nearest gram using a balance (GT2100; O’Haus Scale Corp., Florham Park, N.J.), tubers were sliced in half midway between the apical and stem end and patted dry on a paper towel, and each half was evaluated for yellow-flesh intensity on the colorimeter.

An analysis of variance was computed using SAS's GLM procedure (SAS Institute, 1987) for both years on the following variables: average yellow-flesh intensity per block, total tuber yield per block, average tuber weight per block, and the transformed variance of tuber weight. The variance of tuber weights was transformed, using a cubic-root transformation, to conform to distributional assumptions. Each clone's mean was compared to 'Yukon Gold' using the pooled estimates of variance from the analysis.

The data used for the above analyses were the means of all the tubers collected within each block for each clone. In addition, two types of subsampling schemes for measuring yellow-flesh intensity were examined: random subsampling and mean trimming based on a specified percentile interval. The mean trimming method entailed collecting and weighing all tubers for each pedigree within each block. Subsequently, yellowness index measurements were recorded on those tubers whose weight fell within a 
specified percentile interval. The following four percentile intervals based on tuber weights were considered: $10 \%$ to $90 \%, 25 \%$ to $75 \%, 35 \%$ to $65 \%$ and $40 \%$ to $60 \%$. The percentiles were computed for each clone within each block using SAS's UNIVARIATE procedure (SAS Institute, 1988).

\section{Results and Discussion}

The 1991 growing season was dry and hot from June through mid-August. In contrast, the 1992 growing season was cool with adequate moisture. As a result, total tuber yields, mean tuber weights, and the cubic-root transformation of the variance of individual tuber weights were very low in 1991 compared to 1992 (Tables 1 and 2). Under the stressful growing conditions in 1991, four yellow-flesh selections significantly outyielded 'Yukon Gold'. The mean tuber weights of 21 yellow-flesh selections in 1991 were significantly $(\alpha=0.05)$ less than 'Yukon Gold'. Therefore, those clones that yielded significantly more than 'Yukon Gold' did so by producing more tubers, not larger tubers. However, none of the yellow-flesh selections significantly outyielded 'Yukon Gold' in 1992. The mean tuber weights of 16 clones in 1992 were also significantly less than 'Yukon Gold'. In 1992, three of the yellowflesh selections yielded significantly $(\alpha=0.05)$ less than 'Yukon Gold'. These three clones produced fewer and smaller tubers than 'Yukon Gold'. Despite their significantly smaller tuber weights, two clones produced yields not significantly different from 'Yukon Gold' by producing many tubers: B0813-14 and B0813-5. 'Yukon Gold' was significantly more variable in individual tuber weight than 18 of the yellow-flesh selections in 1991 and six of the yellowflesh selections in 1992. The only yellow-flesh selection signifi- cantly more variable for individual tuber weight than 'Yukon Gold' in 1992 was B0811-13. These results suggest that, although 'Yukon Gold' is fairly high yielding, tuber weight is extremely variable. Several yellow-flesh clones yielded at least as much and were less variable in weight than 'Yukon Gold'.

Based on a $t$ test, B0806-13 and B0808-11 were significantly less yellow than 'Yukon Gold' in 1991 and 1992. One clone (B0810-1) was significantly less yellow than 'Yukon Gold' in 1991 , but not in 1992. Four clones were significantly more yellow than 'Yukon Gold' in 1991 and 1992: B0813-14, B0813-17, B0813-4, and B0813-7. These clones had some of the smallest overall yields and mean tuber weights of all clones tested. In general, when the YI E-313 yellow-flesh intensity index was $<50$, tuber flesh color ranged from cream to pale yellow. When the YI E-313 index was $>50$, tuber flesh color was a definite yellow.

Generally, there was an inverse relationship between tuber weight and yellow-flesh intensity. The overall median Spearman correlation coefficients (Snedecor and Cochran, 1967) were -0.27 and -0.31 for 1991 and 1992, respectively. Scatter plots of tuber weights (not shown) revealed some unusually large tubers that had lower values for yellow-flesh intensity and small tubers that had higher values for yellow-flesh intensity. Therefore, simple random subsampling is less efficient than methods that account for this relationship. Subsampling based on a set random sample is also unfeasible because the number of tubers harvested from a given block varied substantially from clone to clone.

Instead of randomly removing tubers, we removed from the sample those tubers that had the largest and smallest weights. The variance of the trimmed mean is reduced by removing the largest and smallest weights but is simultaneously inflated by the reduced

Table 1. Mean tuber weight, mean tuber yield per block, cubic-root transformation of the variance of the YIE-313 index, and the YI E-313 index for the total sample (0-100) and for the 25-75 percentile (based on tuber weights) subsample for yellow-flesh potato clones evaluated in 1991 in Presque Isle, Maine.

\begin{tabular}{|c|c|c|c|c|c|}
\hline \multirow[b]{2}{*}{ Clone } & \multirow{2}{*}{$\begin{array}{c}\text { Mean tuber } \\
\text { wt }(\mathrm{g})\end{array}$} & \multirow{2}{*}{$\begin{array}{c}\text { Mean } \\
\text { yield }(\mathrm{g})\end{array}$} & \multirow{2}{*}{$\begin{array}{c}\text { Transformed } \\
\text { variance }\end{array}$} & \multicolumn{2}{|c|}{ YI E-313 intensity } \\
\hline & & & & $\overline{0-100}$ & $25-75$ \\
\hline$\overline{\mathrm{B} 0180-24}$ & $65.2^{*}$ & $2217^{*}$ & 12.1 & 54.1 & 54.5 \\
\hline B0806-13 & 82.3 & 1757 & 13.6 & $46.7^{*}$ & 46.6 \\
\hline B0808-11 & $53.1^{*}$ & $2104^{*}$ & $10.0^{*}$ & $48.3^{*}$ & $48.0^{*}$ \\
\hline B0808-3 & $63.3^{*}$ & $2238^{*}$ & 12.2 & 51.9 & 52.2 \\
\hline B0808-4 & $46.1^{*}$ & 1569 & $9.1^{*}$ & 52.8 & 52.7 \\
\hline B0809-10 & $56.8^{*}$ & 1950 & $11.4^{*}$ & 52.3 & 52.1 \\
\hline B0809-2 & $26.2^{*}$ & 909 & $5.3^{*}$ & 53.3 & 53.5 \\
\hline B0809-3 & $65.7^{*}$ & 1774 & $10.0^{*}$ & 52.2 & 51.9 \\
\hline B0809-7 & $46.4^{*}$ & 1749 & $9.0^{*}$ & 53.1 & 53.1 \\
\hline B0810-1 & $55.2^{*}$ & 1766 & $9.2^{*}$ & $47.8^{*}$ & $48.5^{*}$ \\
\hline B0810-4 & $68.9^{*}$ & 1836 & 12.0 & 53.6 & 53.9 \\
\hline B0810-7 & 75.7 & 1716 & 13.5 & 55.0 & 54.7 \\
\hline B0811-13 & 78.6 & 1966 & 15.1 & $56.4^{*}$ & $56.4^{*}$ \\
\hline B0811-2 & $44.8^{*}$ & 1405 & $8.6^{*}$ & 54.7 & 54.6 \\
\hline B0811-4 & $59.7^{*}$ & 1213 & $9.3^{*}$ & $58.1^{*}$ & $58.0^{*}$ \\
\hline B0813-11 & $53.2^{*}$ & 1774 & $9.7^{*}$ & 54.1 & 54.2 \\
\hline B0813-14 & $36.5^{*}$ & 1425 & $6.9^{*}$ & $57.8^{*}$ & $58.1^{*}$ \\
\hline B0813-16 & $44.2^{*}$ & 1873 & $9.7^{*}$ & 55.4 & 55.8 \\
\hline B0813-17 & $43.9^{*}$ & 894 & $5.9^{*}$ & $59.7^{*}$ & $59.5^{*}$ \\
\hline B0813-2 & $46.7^{*}$ & 1028 & $8.4^{*}$ & 50.1 & 50.7 \\
\hline B0813-3 & $47.6^{*}$ & $2363^{*}$ & $9.8^{*}$ & 55.4 & 55.7 \\
\hline B0813-4 & $36.0^{*}$ & 1692 & $7.5^{*}$ & $58.6^{*}$ & $58.5^{*}$ \\
\hline B0813-5 & $34.8^{*}$ & 1184 & $7.5^{*}$ & 51.6 & 51.8 \\
\hline B0813-7 & $55.3^{*}$ & 1402 & $9.7^{*}$ & $56.2^{*}$ & 56.0 \\
\hline Yukon Gold & 89.8 & 1317 & 14.6 & 53.7 & 54.0 \\
\hline
\end{tabular}

"Significantly different from 'Yukon Gold' at $P=0.05$. 
Table 2. Mean tuber weight, mean tuber yield per block, cube root transformation of the variance of the YI E-313 index, and the YIE-313 index for the total sample (0-100) and for the 25-75 percentile (based on tuber weights) subsample for yellow-flesh potato clones evaluated in 1992 in Presque Isle, Maine.

\begin{tabular}{|c|c|c|c|c|c|}
\hline \multirow[b]{2}{*}{ Clone } & \multirow{2}{*}{$\begin{array}{l}\text { Mean tuber } \\
\text { wt }(\mathrm{g})\end{array}$} & \multirow{2}{*}{$\begin{array}{c}\text { Mean } \\
\text { yield }(\mathrm{g})\end{array}$} & \multirow{2}{*}{$\begin{array}{c}\text { Transformed } \\
\text { variance }\end{array}$} & \multicolumn{2}{|c|}{ YI E-313 intensity } \\
\hline & & & & $0-100$ & $25-75$ \\
\hline$\overline{B 0180-24}$ & $151.6^{*}$ & 5813 & 18.9 & $53.2^{*}$ & $53.5^{*}$ \\
\hline B0806-13 & 152.6 & 4882 & 20.8 & $46.3^{*}$ & $46.5^{*}$ \\
\hline B0808-11 & $137.9^{*}$ & 5380 & 14.8 & $47.2^{*}$ & $46.8^{*}$ \\
\hline B0808-3 & $132.1^{*}$ & 5021 & 14.0 & $53.8^{*}$ & $54.0^{*}$ \\
\hline B0808-4 & $149.5^{*}$ & 4586 & 17.4 & $54.5^{*}$ & $54.4^{*}$ \\
\hline B0809-10 & $144.0^{*}$ & 4225 & 17.4 & 48.3 & 48.0 \\
\hline B0809-2 & $98.5^{*}$ & $2987^{*}$ & $10.8^{*}$ & $52.3^{*}$ & 52.6 \\
\hline B0809-3 & $142.9^{*}$ & 4477 & 18.1 & 51.2 & 51.5 \\
\hline B0809-7 & $120.1^{*}$ & 3802 & $13.2^{*}$ & 52.2 & 52.0 \\
\hline B0810-1 & $134.5^{*}$ & 5334 & 16.0 & 50.5 & 50.4 \\
\hline B0810-4 & 163.9 & 4864 & 18.7 & $54.5^{*}$ & $54.5^{*}$ \\
\hline B0810-7 & 155.6 & 5290 & 16.7 & $53.5^{*}$ & $54.0^{*}$ \\
\hline B0811-13 & 187.5 & 6063 & $25.2^{*}$ & 52.0 & 51.8 \\
\hline B0811-2 & 162.5 & 6068 & 20.5 & 51.5 & 51.5 \\
\hline B0811-4 & $133.0^{*}$ & 3856 & 16.8 & $53.8^{*}$ & $54.0^{*}$ \\
\hline B0813-11 & 171.2 & 4281 & 18.5 & 48.4 & 48.5 \\
\hline B0813-14 & $102.7^{*}$ & 4380 & $12.2^{*}$ & $52.8^{*}$ & $53.0^{*}$ \\
\hline B0813-16 & $133.9^{*}$ & 4732 & 15.4 & 48.4 & 48.2 \\
\hline B0813-17 & $90.9^{*}$ & $3395^{*}$ & $12.9^{*}$ & $58.5^{*}$ & $58.6^{*}$ \\
\hline B0813-2 & 155.7 & 4879 & 16.6 & 48.7 & 48.4 \\
\hline B0813-3 & $152.7^{*}$ & 5852 & 16.0 & 51.8 & 51.8 \\
\hline B0813-4 & $103.9^{*}$ & $3291^{*}$ & $10.0^{*}$ & $55.9^{*}$ & $55.9^{*}$ \\
\hline B0813-5 & $109.6^{*}$ & 3946 & $11.2^{*}$ & 50.5 & 50.7 \\
\hline B0813-7 & 162.0 & 4104 & 15.6 & $54.5^{*}$ & $54.5^{*}$ \\
\hline Yukon Gold & 183.2 & 5223 & 18.9 & 50.1 & 50.1 \\
\hline
\end{tabular}

*Significantly different from 'Yukon Gold' at $P=0.05$.

sample size. The objective was to identify a percentile interval that significantly decreased the sample size without seriously affecting the results of the clonal comparisons. This can be achieved by using the 25 to 75 percentile interval (Tables 1 and 2 ). This reduced the overall median Spearman correlation coefficients (Snedecor and Cochran, 1967) to -0.08 and -0.22 for 1991 and 1992, respectively. Furthermore, selecting those tubers whose weight fell within the 25 to 75 percentile interval satisfactorily reduced the cost of evaluating yellow-flesh intensity by decreasing the sample size by about one-half.

The role of individual tuber size, as measured by weight, on the yellow-flesh trait has been verified in this study. Subsampling techniques that reduce the sampling size for determining yellowflesh intensity but preserve the consistency of pairwise comparisons should allow for the influence of unusually large or small tubers. In this study, there was good agreement between results from the 25 to 75 percentile range and the total sample.

There were significant differences in yellow-flesh intensity among the clones. Thus, it should be possible to breed for more intense yellow-flesh varieties. Further studies to verify the possible importance of modifying genes on the yellow-flesh trait and to investigate the role of genotype $\times$ environment interactions on the expression of the yellow-flesh trait are necessary.

\section{Literature Cited}

American Society for Testing Materials. 1991. ASTM standards on color and appearance measurement. 3rd ed. Amer. Soc. Testing Materials, Philadelphia. p. 239-242.
Bonierbale, M.W., R.L. Plaisted, and S.D. Tanksley. 1988. RFLP maps based on a common set of clones reveal modes of chromosomal evolution in potato and tomato. Genetics 120:1095-1103.

Brown, C.R., C.G. Edwards, C.P. Yand, and B.B. Dean. 1993. Orange flesh trait in potato: Inheritance and carotenoid content. J. Amer. Soc. Hort. Sci. 118:145-150.

Fruwirth, C. 1912. Zur Zuchtung der Kartoffel. Dtsch. Landw. Presse 39:551-552, 565-567.

Iwanzik, W., M. Tevini, R. Stute, and R. Hilbert. 1983. Carotinoidgehalt und-Zusammensetzung verschiedener deutscher Kartoffelsorten und deren Bedeutung fur die Fleischfarbe der Knolle. Potato Res. 26:149_ 162.

Johnston, G.R. and R.G. Rowberry. 1981. Yukon Gold: A new yellowfleshed, medium-early, high quality table and French-fry cultivar. Amer. Potato J. 58:241-244.

National Potato Council. 1993. 1993 Potato statistical yearbook. Natl. Potato Council, Englewood, Colo.

Pendlington, S., M.S. DuPont, and F.J. Trussell. 1965. The carotenoid pigments of $S$. tuberosum. Proc. Biochem. Soc. p. 25-26.

SAS Institute. 1987. SAS/STAT guide for personal computers. version 6. SAS Inst., Cary, N.C.

SAS Institute. 1988. SAS procedure guide. release 6.03. SAS Inst., Cary, N.C.

Schick, R. 1956. Methoden und Probleme der Kartoffelzuchtung. Zber. dtsch. Akad. LandWiss. Berl. 5(29):1-40.

Siebenick, H. 1959. Beobachtungen an derFleischfarbe der rohen Kartoffel. European Potato J. 2:229-236.

Sinden, S.L., K.G. Haynes, and F. Khachik. 1991. Association of betacarotene with total carotenoid content in white- and yellow-fleshed potatoes. Amer. Potato J. 68:635.

Snedecor, G.W. and W.G. Cochran. 1967. Statistical methods. 6th ed. Iowa State Univ. Press, Ames. 